\title{
肩甲骨棘付き僧帽筋皮弁による下顎再建手術
}

$\begin{array}{lrrr}\text { 木村 } & \text { 洋・ 中村 } & \text { 正・ 戸島 } & \text { 均 } \\ \text { 金山 } & \text { 亮治・深瀬 } & \text { 滋・布施 } & \text { 健生 } \\ \text { 小池 } & \text { 吉郎 } & & \end{array}$

\section{Trapezius Osteomyocutaneous Flap in Reconstructive Surgery for Mandibular and Oral Defects}

\author{
Yo Kimura, Tadashi Nakamura, Hitoshi Tojima, Ryoji Kanayama, \\ Shigeru Fukase, Takeo Fuse and Yoshio Koike \\ (Yamagata University)
}

\begin{abstract}
Reconstruction of the mandibular arch after ablative surgery of the oral cavity is extremely difficult. Recently, in cases of more complex defects, including bone and soft tissue loss, an osteomyocutaneus flap is commonly used for one-stage repair. This study examines the trapezius myocutaneous flap incorporating the spine of the scapula in reconstructive surgery for mandibular and oral defects.

We utilized this technique in 3 patients with oral cavity carcinoma. All the patients had been irradiated and treated with anti-cancer drugs before operation. In one patient this technique failed because of stagnant venous return caused by an intraoperative procedure. Reconstruction was performed by a compound rib-latissimus dorsi osteomyocutaneous flap two days after operation. All the patients had successful healing with excellent esthetic and functional resuslts. The ${ }^{99 \mathrm{~m}} \mathrm{Tc}$ labeling bone scan and panorex radiographs showed evidence of active bony turnover. The spine of the scapula-trapezius osteomyocutaneous flap is thus useful for repair procedures for mandibular and oral defects.
\end{abstract}

Key words: trapezius osteomyocutaneous flap, spine of the scapula, mandibular and oral defects

はじめに

口腔癌や咽頭癌の手術に括いて，下顎骨の処 理をどらするかについてはいまだ定説がなく， 症例に応じ，また術者の経験や技量に応じ対応 されている.下顎骨はその機能と形態からみて， 腫瘍が安全に切除されるならば可能な限り保存 されるべきものと考えるが，合併切除を余儀な
くされる症例も多く存在する．また，切除後の 下顎骨再建には種々の方法が試みられてきてい るが，それぞれに一長一短があり，まだ確立さ れた方法はないのが実状である。

われわれは口腔癌に扣いて，下顎骨区域切除 後, 肩甲骨棘付き有茎僧帽筋皮弁を用いて再建 を行い，良好な結果を得たので，手術手技を中 
心に報告し，下顎再建の問題点などについて考 察する。

\section{対 象}

本法を適用したのは 3 症例で，いずれも口腔 癌(扁平上皮癌)である。症例のまとめは表 1 亿, また切除範囲の概略は図 1 に示す。

症例 $1 \cdot 3$ は再発症例であるが，全症例に前 治療あるいは術前治療として放射線照射を行っ ている，下顎骨の切除範囲はいずれも正中を越 えず，一側体部のみである.

\section{手術方法}

口腔内腫瘍の摘出和よび下顎骨区域切除につ いては成書に譲る。本法の要点を Demergasso らの原法(1976，1979)112) および Defresne らの 追試報告(1986) 3) を基に図 2 亿示し，要点を以 下に記す。

1 ）最も大切なことは輸出入血管である頸横 動静脈を損傷しないよらにすることと, 術後の 皮弁萎縮を防止する為に, 可能ならば副神経を 保存することである。

表 1

\begin{tabular}{|c|c|c|c|c|c|c|c|}
\hline 症例 & 年歯令 & 性 & 部位 (TNM) & 病理組織型 & 術前経過 · 治療 & 手術日 & 術後治療 \\
\hline 1 & 68 & 男 & $\begin{array}{c}\text { 口腔底 } \\
\left(\mathrm{rT}_{3} \mathrm{~N}_{1} \mathrm{M}_{0}\right)\end{array}$ & 扁平上皮癌 & $\begin{array}{l}\text { (1) } 1986.2 .3 \sim 5.7 \\
\text { FAR (30Gy), レーザー手術 } \\
\text { 動注 (CDDP } 84 \mathrm{mg}, \text { PLM } 35 \mathrm{mg}) \\
\text { (2) } 1988.6 .27,7.25 \\
\text { レーザー手術 }\end{array}$ & 1989. 3. 5 & $\begin{array}{l}\text { CDDP } 200 \mathrm{mg} \\
5 \mathrm{Fu} 2000 \mathrm{mg}\end{array}$ \\
\hline 2 & 62 & 男 & $\begin{array}{c}\text { 歯肉 } \\
\left(\mathrm{T}_{4} \mathrm{~N}_{1} \mathrm{M}_{0}\right)\end{array}$ & 扁平上皮癌 & $\begin{array}{l}\text { 術前照射 } 30 \mathrm{~Gy} \\
\text { 動注 (CDDP } 75 \text { mg, 5Fu } 375 \mathrm{mg} \text { ) }\end{array}$ & 1989.11 .14 & $\begin{array}{l}\text { CDDP } 100 \mathrm{mg} \\
\text { THPADM } 90 \mathrm{mg}\end{array}$ \\
\hline 3 & 62 & 男 & $\begin{array}{c}\text { 舌 } \\
\left(\mathrm{rT}_{3} \mathrm{~N}_{2} \mathrm{M}_{0}\right)\end{array}$ & 扁平上皮癌 & $\begin{array}{l}1989.6 .2 \sim 9.8 \\
\text { 外照射 } 25 \mathrm{~Gy} \\
\mathrm{Ra} \text { 針 } 64 \mathrm{~Gy}\end{array}$ & $\begin{array}{c}1989.11 .28 \\
1989.11 .30 \\
\text { (再手術)* }^{*}\end{array}$ & 照射 $40 \mathrm{~Gy}$ \\
\hline
\end{tabular}

A

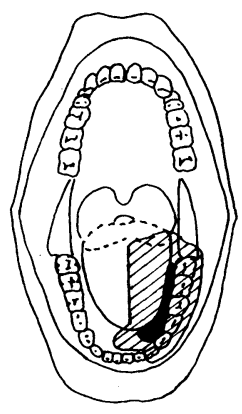

B

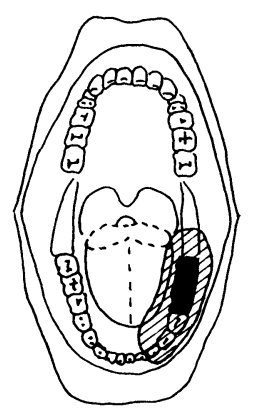

C

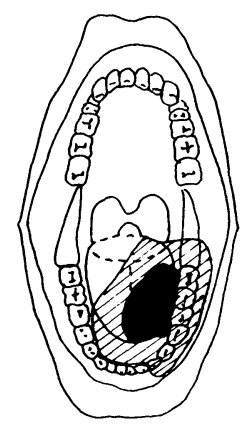

図 1 切除範囲の概略
$A$ : 症例 1 (口腔底癌 $\mathrm{rT}_{3} \mathrm{~N}_{1} \mathrm{M}_{0}$ )
$B$ : 症例 2 （歯肉癌 $\mathrm{T}_{4} \mathrm{~N}_{1} \mathrm{M}_{0}$ )
$\mathrm{C}:$ 症例 3 (舌癌 $\mathrm{rT}_{3} \mathrm{~N}_{2} \mathrm{M}_{0}$ )

黒塗 : 腫瘍範囲 斜線部 : 切除範囲 
2 ）皮弁は頸部郭清術を行ら際の皮切を肩甲 骨棘部の皮弁となる部まで延長する.

3 ) donor となる皮弁は口腔内の欠損部に応 じた大きさとし，肩甲棘の長軸方向に長い楕円 形の軸を持つデザインが望ましい，

4 ）皮膚切開後，皮下脂肪・筋膜 - 僧帽筋之 切開し，僧帽筋後面を剥離し肩甲棘に到達する。 その後, 棘上筋・棘下筋・三角筋を付着部で切 離する，骨膜上にて棘部を露出し下顎骨の欠損 に応じて必要な骨を採取する，僧帽筋の筋体量 は軟部組織の欠損に応じて調節する。

5 ）骨は肩峰部まで採取できるが，術後の

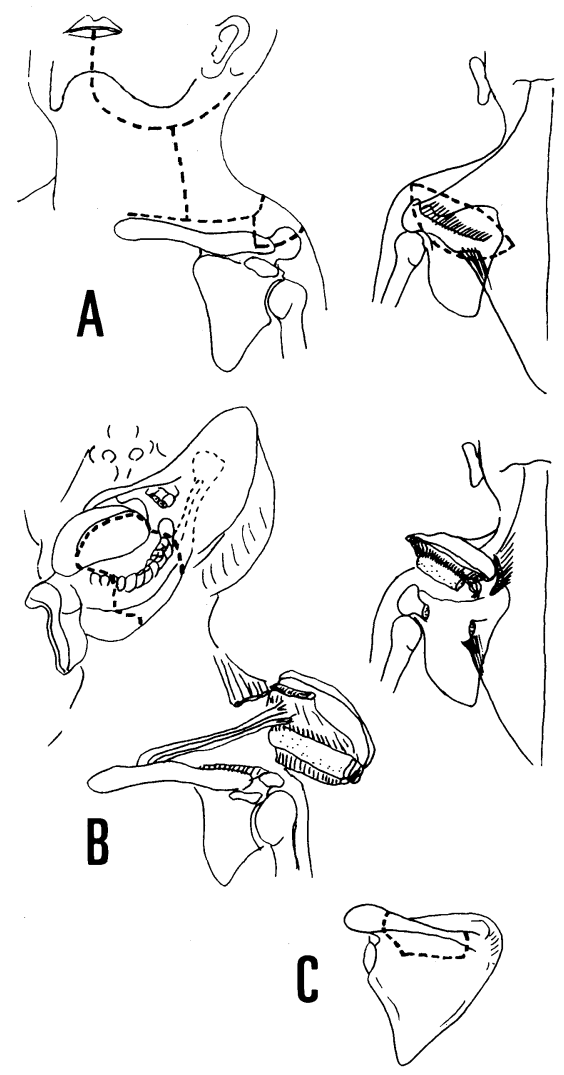

図 2 手術術式

$\mathrm{A}$ ：皮切执よび皮弁作図.

B：口腔と下顎区域切除ならびに肩甲骨棘付 き僧帽筋皮弁の採取. 栄養血管である頸 横動脈を損傷しないよらに注意する。

C：肩甲骨棘部の骨採取. donor 部の機能障害を考えて肩峰は避けて肩甲 棘のみとした方がよい.

6 ）僧帽筋と棘部の結合はかなり密であるが, 剥離しないように細心の注意を払ら。

7 ）皮弁摘出後の死腔は棘上筋，棘下筋，三 角筋等で充媜するよらに縫合し，欠損部をカ バーする.

8）皮膚欠損部は大きさにもよるが，汪とん どが一次縫合可能である.

以上の方法に従って 3 例の手術を行ったが， 実際の症例については, 症例 2 を呈示し, 術前 の状態(図 3 左, 図 4 ), 術中所見(図 5 ), 術後 の状態(図 3 右, 図 $6 \cdot 7$ ) を示す.

\section{手術成績}

症例 1,2 はいずれも骨は生着した。

症例 1 では術後20日目より流動食を, 症例 2 では術後30日目より重湯を経口摂取し，両者と もに現在特に硬いもの以外は普通食を摂取して いる。 また，開口，咬合，会話を含めて日常生 活に特に大きな支障はない状態である。術後の 骨生着の状態を骨シンチグラムの所見として図 8 に示す。

症例 3 については, 頸横静脈自体が細かった 事と，剥離操作や分枝の処理などを加穴る際に 一部括れを生じ茎が細くなった所があった。し かし，術中を通じ特に静脈還流に支障を認めな かったので，そのまま皮弁を再建に用いた。術 翌日夕方までは皮弁の状態に変化は認められな かったが，夜間から早朝にかけて皮弁血行不全 による皮弁壊死を認めた為, 術後 2 日目に再手 術を行った，その際の所見では，括れ込久の部 分を中心として静脈血栓により完全閉塞の状態 に陥って扮り，皮弁生着は無理と判断し，有茎 胁骨付き広背筋皮并を用いて再建し直した。こ の症例も骨は生着したが，舌亜全摘に近い症例 であった為か，軟食の摂取となり，発語明瞭度 も話の内容を知れば判る程度の機能回復であっ た。

3 症例ともに, donor 部の機能障害は認めな かった。 
考察

今回われわれは，Demergasso らの方法12) をDefresne らが詳しく報告した方法3) 飞従っ て，有茎肩甲骨棘付き僧帽筋皮弁を用いて， 3
例の下顎再建を行ったが，下顎再建に拈ける本 皮弁の有用性と問題点を中心に考察する.

僧帽筋の大半は頸横動脈を主栄養動脈として おり，肩甲骨棘部は僧帽筋付着部であり，筋と

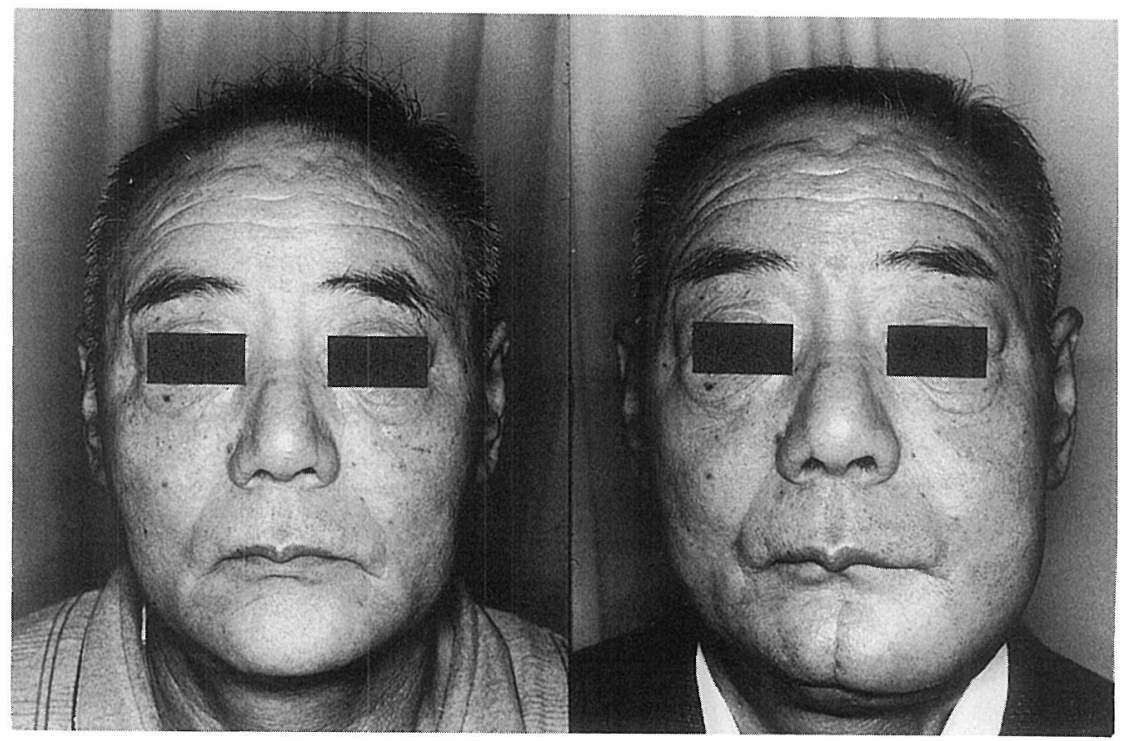

図 3 術前 $($ 左)・術後 6 力月 (右)の顔貌

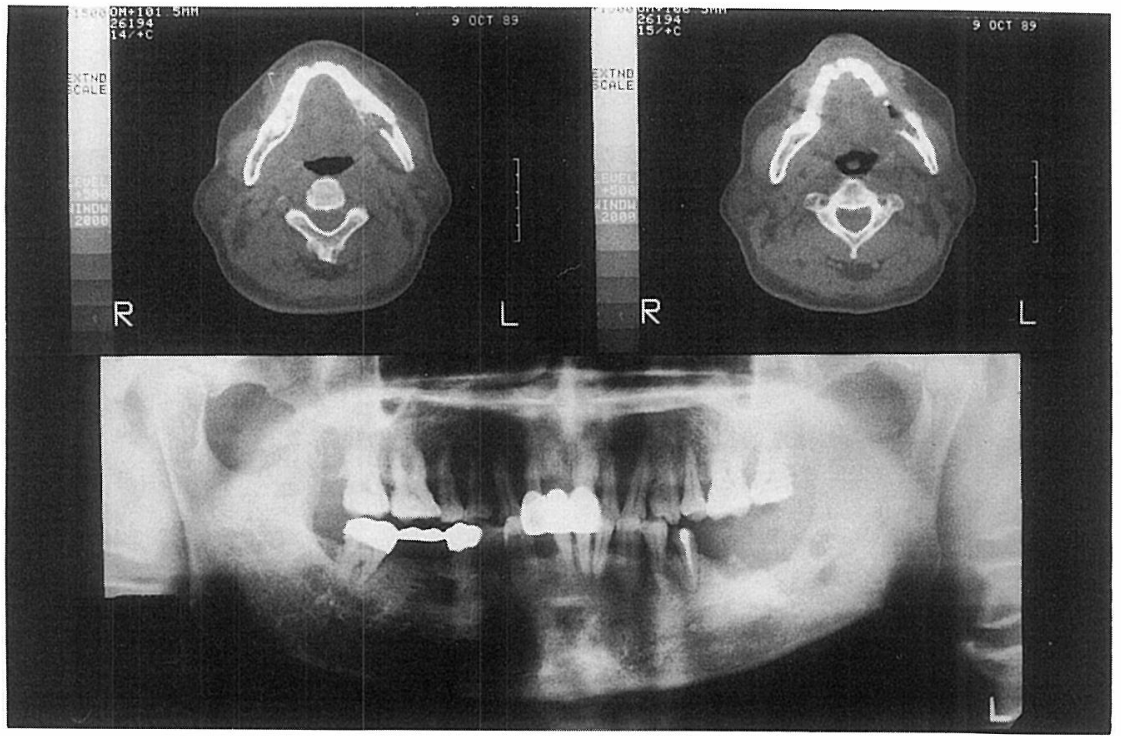

図 4 術前レントゲン所見 (症例 2)

上段：CT 所見.下段：パノラマ撮影。両所見とも下蕦骨の吸収・破壊像が認めら れる. 
骨との結合は極めて密であり，同部は頸横動脈 から骨膜栄養支配を受けている3)。骨栄養血管 は主栄養動脈, 骨端部動脈, 骨膜動脈飞分類さ れているが，主栄養動脈と骨膜動脈とは移植骨 の生存に差のないことが確認されて和り3) 5), 骨膜動脈栄養支配である本皮弁の安全性は裏付 けられている。

次に，血管茎となる頸横動脈济破格が多いと いら問題については, 確かに起始部の異常は多 く, 大部分は下甲状腺動脈から分岐するが，約 20〜30\%は鎖骨下動脈から起こるとされてい る3).しかし，本動脈を欠くものは極めて稀で あり，本法適応に際して特に支障とはならない と考光る. 従って，本法を行らに当たっては， 頸部郭清術を行う場合に本動脈を損傷しないよ らに十分注意することは当然であるが, 郭清術
中に頸横動脈を僧帽筋前縁まで同定しておくこ とは再建を円滑に行らのに必要である。また， 郭清術と同時に血管荎の剥離が行えることは本 法の利点でもある。ささら動脈のみならず伴走 する静脈についても，動脈に対してと同じく， あるいはそれ以上の注意を払って処理する必要 がある。一般に伴走静脈は径が細いので, 剥離 し過ぎたり，損傷したりしないようにしなけれ ばならない。われわれは症例 3 では菱を細くし 過ぎた為か，あるいは分枝の処理中に一部損傷 した為か, 静脈還流障害により皮弁壞死を来し た苦い経験があり，血管荎の伸展のし過ぎや屈 曲に注意するとともに十分愛護的に処理しなけ ればならないことが痛感された。可能な限り術 前に血管造影を施行し, 本動脈の走行, 起始部 などについて確認する力がよいと考える.

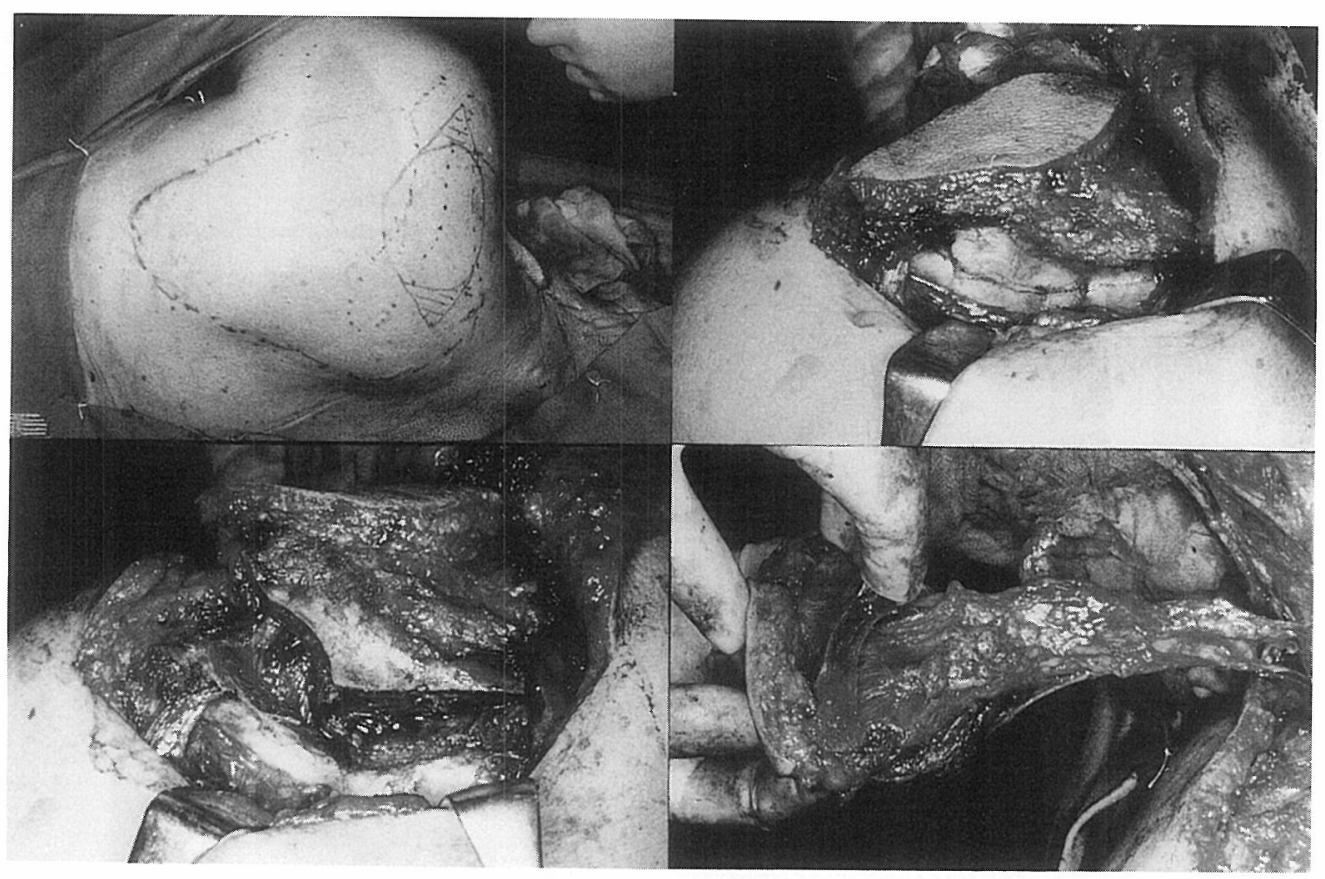

図 5 術中所見 (症例 2)

上段左：皮弁作図.

上段右：僧帽筇を剥離し肩甲骨棘部付着部を露出.

下段左：棘部をノミとドリルで切離.

下段右：皮弁採取完了。栄養血管である頸横動静脈を示す. 


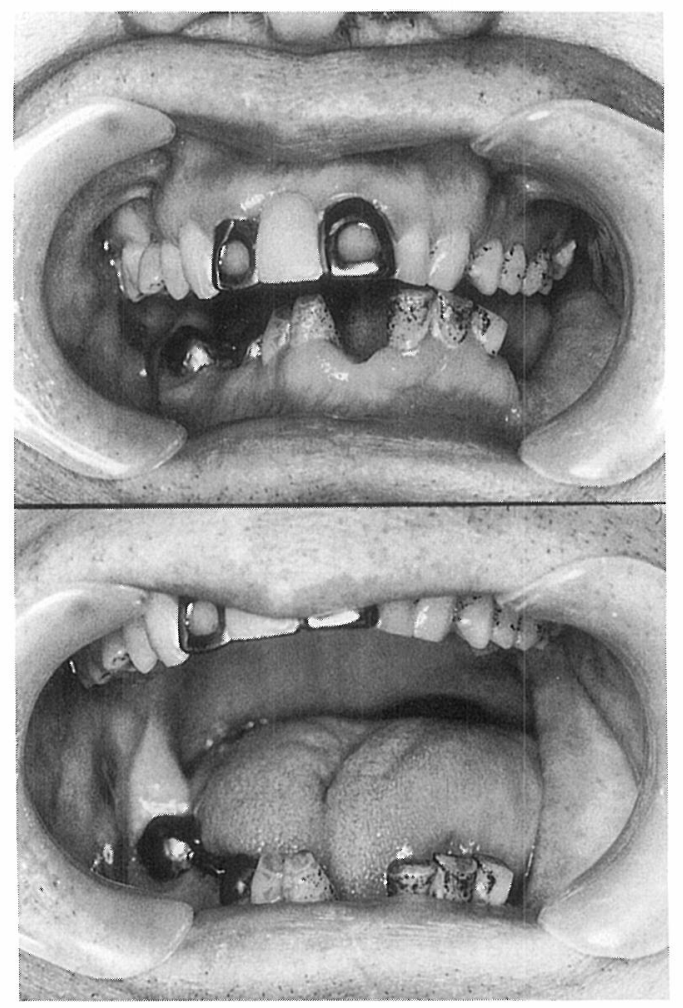

図 6 術後の口腔所見 (症例 2)

開口・咬合の状態を示す (術後 1 年).
手術の要点は手術方法の項で述べたが，血管 茎の処理以外の手術の注意点などについて，付 け加点る。棘部の採取にあたっては肩峰部まで 含める事は可能であるが3)，肩甲骨の回旋の中 心を欠く事となり，上腕の機能障害を来す恐れ があり避けた汪らがよい。また，皮弁採取後の 欠損部は切離した䊂上筋・棘下竻・三角笳の断 端を密に縫合し，死腔を充填する事が必要であ る.これにより肩関節運動による哆開を防止

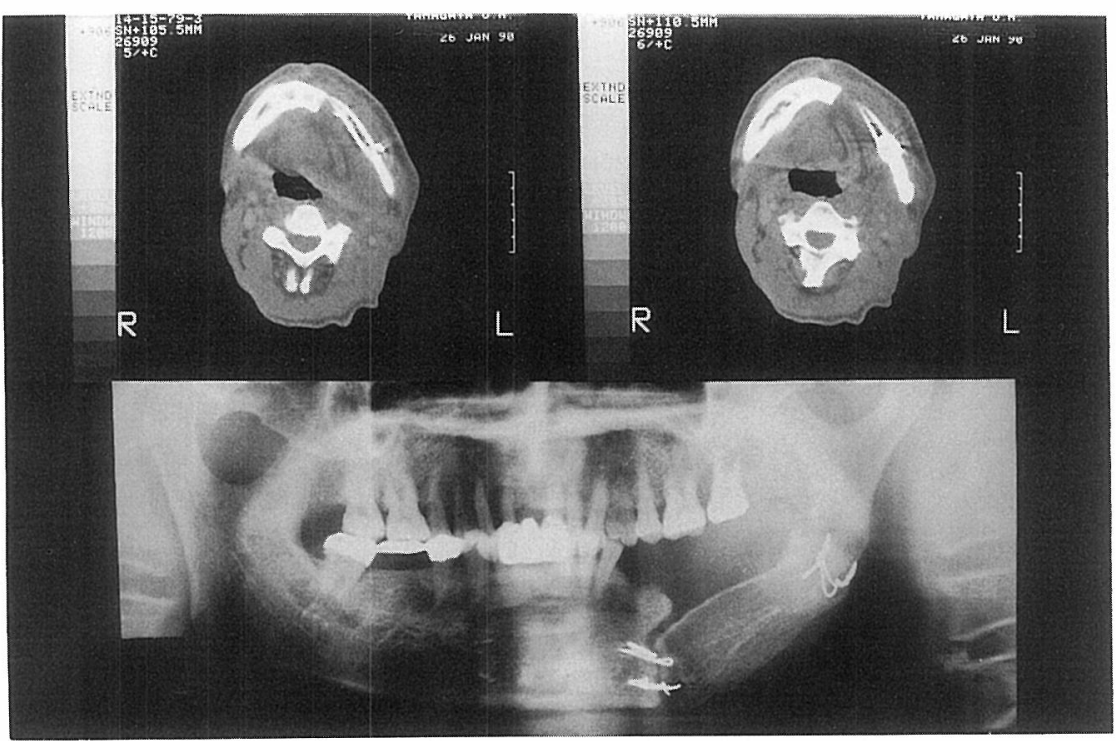

図 7 術後レントゲン所見(症例 2)

上段 : CT 所見. 下段 : パノラマ撮影. 
でさるし，機能障害も来さない。皮膚欠損部は 特に大きな皮弁でない限りは頸部郭清術創とと もに一次縫合可能であり, 体位変換は必要では あるが, donor 部は背部であり整容的に優れて いる。

次に，移植骨の生着とその評価についての問 題であるが，骨への血行は皮弁挙上時の骨端か らある程度把握でき，また皮弁の生着によって も亦程度の指標とすることができる。しかし， 移植骨の経過については術後, 経時的にX線撮 影を行い，骨化・癒合状態を確認するとともに， 骨吸収像・破壊像・硬化像など異常の有無につ いても観察する必要がある．特に骨シンチグラ フィーは移植骨生存の有用な判定法であり, 移 植部の取り込及像は吻合部血流の存在を示唆 し6)，移植骨生存を評価できるものといえる。 検査の時期は 3 日〜 4 週との報告があり，いず れも有用であったとしているが344)6)，実際的に は 1 週目位が妥当なところではないかと思われ る。移植骨の癒合に関しては， living boneの 移植の場合には骨折の治癒過程と同様の過程を 介して骨の癒合が得られ，一次治癒に向からも のと推察される4)。これに対して，遊離骨移植 の場合には骨栄屓動脈の血行遮断により, 移植 骨の大部分は壊死に陥り吸収されると同時に移 植床由来の骨芽細胞により骨再構築が行われる か788)，一部骨膜からの骨新生も認められると いら9110)。いずれにしても移植骨の場合には移 植床の状態により骨の生存は左右されることに なる．従って，悪性腫瘍摘出術に伴う再建の場 合には放射線照射や化学療法などの治療を受け ている例も多く，骨栄養血管の血行を温存した living bone の移植が望ましいといえる.

最後に，下顎再建といら面からわれわれの経 験を基に，本法1) 3) と他の種々の方法410) 13) とを比較検討してみる．長所としては，(1)肩甲 棘部は下顎体部の形状に近く，しか子厚みがあ り，骨強度も強いことが挙げられる。また，筋 皮弁としての厚みもあり, bulky な皮弁を必要 とされる下顎合併切除例の口腔再建に適してい
る。(2)頸横動静脈を血管茎とする有茎弁である ので，血管茎の処置を確実に行えば安全性は高 く，放射線治療や化学療法などを受けていて移 植床の状態不良の症例にも安全に行兄る. (3)donor 部の機能障害も少なく，背部であるの で整容的に見ても問題は少ない，(4)体位変換は 必要であるが，血管茎の処理を頸部郭清術と同 一視野で行らことがでさるし，半側臥位にすれ ば， donor 部の縫合と口腔内执よび移植骨の処 理を同時に行える。(5)頸部郭清術創とdonor 部を同時に一期的に縫合することが可能である. (6)胁骨付き広背筋皮弁に和ける開胸の危険性が ない，などが挙げられる。

短所としては，(1)弯曲をつけることが難しく， オトガイ部を含む形成は比較的困難である. (2) 有菱である利点もある反面, 移動距離に制限が あるので，血管茎付き遊離骨移植に比し自由度 は高くない，しかし，血管茎は十分長いので口 腔内再建には支障はない。(3)頸横動脈の破格が あること，伴走静脈の茎が比較的細いものが多 く, 静脈らっ滞の危険性がある. (4)頸部郭清術 時に頸横動静脈を残せない場合には，本法は適 応できない，ことなどが挙げられる。

以上であるが，下顎再建の目的である咀嚼機 能・言語機能の保持, 顔面の変形防止による形 態の保持については満足すべき結果が得られる ものと考兵る。咀嚼機能と言語機能は口腔癌の 場合には残存する舌機能に左右される面があり, 一概には判断できない面がある。最近では，血 管茎付き遊離骨移植, 特に肩甲回旋動脈柄付き 肩甲骨皮弁が自由度も高く，血管柄も太く繁用 される傾向にあり, 現時点では最善の方法と言 えるかもしれない10121213)。しかし，種々の事情 で遊離移植を行えない症例も多くあり，骨付き 有茎弁移植も十分有用性が高いものと言学る. 放射線や化学療法を受けている症例に対しても, 血管柄の処理を誤らなければ安全に行える方法 と思われた。

\section{まとめ}

1 ）口腔癌の 3 症例に対し，下顎区域切除後 
の再建に肩甲骨棘付き有茥僧帽筋皮弁を用いた。

2） 2 例は皮弁・骨ともに生着し，機能的に も形態的にも満足すべき結果であった。

3） 1 例は静脈還流障害にて皮弁壊死に陥っ た為，胁骨付き広背筋皮弁で再建し直した。

4) donor 部の機能障害は匡とんど認められ ず，背部であるので整容的にも優れている。

5 ）本皮弁は頸横動静脈を血管柄とする骨付 き複合弁であり，下顎欠損を合併した口腔の広 範囲組織欠損の再建に有用な手術法と思われた。

本手術の施行にあたり，御助言・御助力をいただ いた本学医学部整形外科学教室の後藤康夫先生に厚 く御礼申し上げます。

\section{文献}

1) Demergasso $F$ : Colgajo cutaneo asilado a pediculo musucular ; nueva tecnica reconstructiva de cavided oral en cancer de cabeza y cuello. Acta Soc Cir Rosario 32 : 27, 1976.

2) Demergasso F and Piazza MV: Trapezius myocutaneous flap in reconstructive surgery for head and neck cancer ; an original technique. Am J Surg 138 : 533 536, 1979.

3) Defresne C, Cutting C, Valauri F, et al : Reconstruction of mandibular and floor of mouth defects using the trapezius osteomyocutaneous flap. Plast Reconstr Surg $79: 687$ $\sim 695,1986$.

4) 大西 清, 丸山 優, 張 正忠, 他 : 肋骨広背 筋皮弁の応用と評価. 日形会誌 $7: 402 \sim 416$, 1987.

5) Ariyan $\mathrm{S}:$ The viability of rib grafts trans- planted with the periosteal blood supply. Plast Reconstr Surg $65: 140 \sim 151,1980$.

6) Bos KE : Bone scintigraphy of experimental composite bone grafts revascularized anastomoses. Plast Reconstr Surg 64 : 353 360, 1979.

7) Abbott LD, Schottstaedt ER, Saunders JBDM, et al : The evaluation of cortical and cancellaous bone as grafting material. J Bone Joint Surg $29: 381 \sim 414,1987$.

8) Phemister DB : The fate of transplanted bone and regenerative power of its various constituents. Surg Gynecol Obstet $19: 303 \sim 333$, 1914.

9）生田義和, 菅田 巌, 安達長夫, 他：血管柄付 遊離骨移植の手技とその問題点. 災害医学 21 : 1131 1140, 1978.

10）高戸 毅，波利井清紀，中塚貴志，他：血管柄 付骨移植に関する研究一第 1 報 : 遊離骨移植 との比較一. 日形会誌 5:487〜 504, 1985.

11）川端一嘉 : 舌口腔底癌における下顎骨の処理. 頭頸部腫瘍 $16: 48 \sim 51,1989$.

12）山田 敦, 波利井清紀, 中塚貴志: 頭頸部癌切 除後の再建手術一マイクロサージャリーによ る組織移植の応用一.外科診療 $31: 1667 \sim 1679$, 1989.

13) Teot L, Bosse JP, Moufarrege R, et al : The scapular crest pediculed bone graft. Int $\mathrm{J}$ Microsurg $3: 257 \sim 262,1981$.

$\left(\begin{array}{l}\text { 原稿受付 : 平成 } 3 \text { 年 } 4 \text { 月 } 17 \text { 日 } \\ \text { 原稿採択 : 平成 } 3 \text { 年 } 6 \text { 月 } 26 \text { 日 急載 } \\ \text { 別刷請求先 : 木村 洋 } \\ \text { 干990- } 23 \text { 山形市飯田西2-2-2 } \\ \text { 山形大学医学部耳鼻咽喉科学教室 }\end{array}\right)$

